\title{
MEMBATASI TANPA MELANGGAR
}

\author{
Abdul Jamil Wahab \\ Peneliti Puslitbang Bimas Agama dan Layanan Keagamaan \\ Badan Litbang dan Diklat Kementerian Agama
}

Judul

Penulis

Penerbit

Cetakan I

: Membatasi Tanpa Melanggar, Hak Kebebasan Beragama atau Berkeyakinan

Tebal

: Zainal Abidin Bagir, Asfinawati, Suhadi, dan Renata Arianingtiyas

Center for Religious and Cross-cultural Studies (CRCS)

: Juni 2019

: x x 114 halaman; ukuran 15 × $23 \mathrm{~cm}$

\begin{abstract}
Abstrak:
Buku ini sangat menarik, setidaknya ada dua alasan. Pertama, tema kebebasan beragama belum banyak ditulis dan dibahas secara serius, padahal persoalan keagamaan paling banyak menjadi variable penyebab konflik di masyarakat. Kedua, para penulis buku ini adalah tokohtokoh kunciyang selama inibanyakterlibat dalam mengkritisi isu-isu kebebasan beragama di tanah air. Dua hal itu saja, cukup menjadi alasan mengapa buku ini penting dibaca dan dikaji dengan serius. Selanjutnya, mengingat muatan buku ini yang sensitif, rumit, dan kompleks, tentu tidak mudah memberikan ulasan atas buku ini, sehingga saya kemudian menggunakan cara yang agak tidak biasa. Saya memulai dengan mendeskripsikan secara singkat isi buku ini, kemudian di bagian akhir, barulah saya memberikan ulasan dan komentar atas buku ini.
\end{abstract}

Kata kunci: Kebebasan Beragama, Komnas HAM, Sirakusa, Moral Masyarakat, Jam'iyyatul Islamiyah

Dalam konstitusi kita, selain terdapat pasal yang menjamin kebebasan beragama dan berkeyakinan (KBB), juga terdapat pasal yang mengatur pembatasan suatu aktivitas keagamaan, misalnya Pasal 28J UUD 1945 dan amandemennya yang menyatakan: "Dalam menjalankan hak dan kebebasannya, setiap orang wajib tunduk kepada pembatasan yang ditetapkan dengan undang-undang dengan maksud semata-mata untuk menjamin pengakuan serta penghormatan atas hak dan kebebasan orang lain dan untuk memenuhi tuntutan yang adil sesuai dengan pertimbangan moral, nilai-nilai agama, keamanan, dan ketertiban umum dalam suatu masyarakat demokratis". Dengan demikian, tidak ada kebebasan mutlak.

Pembatasan atas KBB juga tercantum dalam Kovenan Internasional Hak-Hak Sipil dan Politik (International Covenant on Civil and Political Rights/ ICCPR) yang telah diratifikasi Indonesia melalui UU No. 12 /2005. Pasal 18 (3) ICCPR yang menyatakan, "Kebebasan menjalankan dan menentukan agama atau kepercayaan seseorang hanya dapat dibatasi oleh ketentuan berdasarkan hukum, dan yang diperlukan untuk melindungi keselamatan, ketertiban, kesehatan, atau moral masyarakat, atau hak-hak dan kebebasan mendasar orang lain."

Buku ini mencoba menelisik argumen mengenai keabsahan pembatasan atas KBB, baik secara langsung atau tidak langsung, untuk mendukung kebijakan pembatasan kehidupan beragama di Indonesia, seperti

\begin{tabular}{l|l} 
Jurnal Multikultural \& Multireligius Vol. 19 & No. 2
\end{tabular} 
pembatasan atau pelarangan organisasi keagamaan atau pengusung paham ideologi tertentu, pembatasan siar agama, pembatasan hak individu yang dianggap mengganggu "ketertiban masyarakat" karena pandangan-pandangan atau tindakan-tindakan keagamaannya, bahkan melalui pemidanaan, dan sebagainya.

Buku ini juga menegaskan, dalam wacana HAM, pembatasan hak memang diperbolehkan, jika dilakukan untuk melindungi ketertiban masyarakat, keselamatan masyarakat, kesehatan masyarakat, dan moral masyarakat. Pertanyaannya adalah apakah argumen pembatasan itu dapat dijustifikasi dengan baik, tidak berlebihan, dan mencapai tujuan pembatasan? Ini adalah persoalanpersoalan besar yang dalam wacana HAM internasional pun masih didiskusikan dengan intensif (hal 3). Melalui penulisan buku ini, diharapkan Komnas HAM dapat membantu penyusunan norma pembatasan KBB di Indonesia yang dapat dimanfaatkan oleh lembaga-lembaga yudisial di Indonesia (hal 4).

Selanjutnya dalam buku ini dijelaskan bahwa persoalan KBB terdiri dari banyak hak keagamaan, menurut ICCPR dan Komentar Umum No. 22, KBB dijabarkan sebagai berikut:

a. Kebebasan untuk memiliki atau menganut agama atau kepercayaan atas pilihannya sendiri, termasuk berpindah atau meninggalkan agama atau kepercayaan (forum internum).

b. Kebebasan untuk mengejawantahkan (to manifest) agama atau kepercayaannya (forum eksternum). Hal ini dijelaskan secara rinci dalam Deklarasi Penghapusan Segala Bentuk Intoleransi dan Diskriminasi berdasar Agama dan Kepercayaan (1981) mencakup: (1) menjalankan agama dan kepercayaannya dalam kegiatan ibadah, (2) memiliki tempat ibadah,
(3) menggunakan/memakai simbolsimbol agama, (4) memperingati harihari besar keagamaan, (5) menunjuk atau memilih pemimpin agama, (6) mengajarkan dan menyebarkan bahan-bahan keagamaan (termasuk melakukan siar agama), (7) hak orang tua untuk memastikan pendidikan agama dan moral bagi anak-anak mereka, (8) berkomunikasi dengan individu dan komunitas tentang urusan agama di tingkat nasional dan internasional, (9) mendirikan dan menjalankan lembaga-lembaga kemanusiaan/mengumpulkan dan menerima pendanaan, (10) mengajukan keberatan yang didasarkan pada hati nurani (conscientious objection).

\section{Pembatasan atas Hak KBB di Indonesia}

Pembatasan atas hak KBB telah ditetapkan dalam beberapa peraturan perundang-undangan, namun beberapa menyebut dengan kalimat yang berbeda-beda. Pertama, dalam UUD 1945, pembatasan disebut di Pasal 28J (hasil Amandemen Kedua, 2000): pembatasan ditetapkan dengan undangundang dengan maksud semata-mata: (1) untuk menjamin pengakuan serta penghormatan atas hak kebebasan orang lain, dan (2) untuk memenuhi tuntutan yang adil sesuai dengan: pertimbangan moral, (3) nilai-nilai agama, (4) keamanan, (5) ketertiban umum, dalam suatu masyarakat demokratis (hal. 6).

Kedua, dalam Kovenan Hak Sipil \& Politik (diratifikasi melalui UU No. 12/2005), pasal 18 ayat (3) menjelaskan bahwa pembatasan harus berdasarkan hukum dan sepanjang diperlukan untuk melindungi: (1) keselamatan masyarakat (public), (2) ketertiban masyarakat, (3) kesehatan masyarakat, (4) moral masyarakat, (5) hak dan kebebasan mendasar orang lain (hal 7). 
Ketiga, dalam UU HAM (No. 39/1999). Ada hal menarik dalam UU tersebut, dalam tiga pasal di UU tersebut, pembatasan disebut secara tidak seragam, yaitu sebagai berikut:

a. Pasal 70 menyebutkan pembatasan untuk (1) menjamin pengakuan serta penghormatan atas hak dan kebebasan orang lain dan (2) untuk memenuhi tuntutan yang adil sesuai dengan: (3) pertimbangan moral, (4) keamanan, dan (5) ketertiban umum.

b. Pasal 73 menyebutkan "semata-mata untuk menjamin pengakuan dan penghormatan terhadap": (1) hak asasi manusia serta kebebasan dasar orang lain, (2) kesusilaan, (3) ketertiban umum, dan (4) kepentingan bangsa.

c. Pasal 23 berbicara tentang adanya kebebasan berpendapat, "dengan memperhatikan": (1) nilai-nilai agama, (2) kesusilaan, (3) ketertiban, (4) kepentingan umum, dan (5) keutuhan Negara (hal. 8).

Menanggapi berbagai pembatasan tersebut, buku ini memberikan solusi, agar dikembalikan pada sebuah penjelasan makna pembatasan yang diterima cukup luas yaitu prinsipprinsip Sirakusa (Syracuse Principles). Prinsip-prinsip ini dirumuskan pada tahun 1984 di Sirakusa, Italia. Motivasi awal perumusan prinsip-prinsip itu adalah penyalahgunaan pembolehan pembatasan oleh pemerintah. Karena seringnya pembatasan ini digunakan oleh pemerintah, para ahli hukum merasa perlu melihat dasar-dasar pembatasan dengan lebih teliti agar implementasi ICCPR dapat dilakukan dengan efektif.

Selanjutnya, buku ini, menetapkan 5 hal alasan pembatasan berdasarkan peraturan perundangan yang ada di tanah air yaitu: (1) ketertiban masyarakat, (2) keselamatan masyarakat, (3) kesehatan masyarakat, (4) moral masyarakat dan nilai-nilai agama. Pembatasan tersebut kemudian dilihat dengan prinsip-prinsip Sirakusa. Inilah inti dari pembahasan buku ini yang belum banyak dibahas oleh pihak lain, sehingga isi buku ini menjadi sangat penting untuk dipertimbangkan.

\section{Ketertiban Masyarakat}

Menurut buku ini, dalam Prinsip Sirakusa, public order diterjemahkan sebagai "tatanan masyarakat" atau "tatanan sosial". Penerjemahan ini mengisyaratkan bahwa konsep ini berbicara tentang tatanan sosial yang lebih luas, tidak semata-mata ketertiban dalam arti sempit. Adapun di Indonesia, istilah public order atau "ketertiban umum" kerap diterjemahkan secara sederhana sebagai lawan dari ketidaktertiban atau kekacauan (disorder).

Dalam buku ini, lebih lanjut dijelaskan bahwa, kerap kali kriteria "mengganggu ketertiban umum" yang digunakan dalam kasus-kasus penodaan agama, lebih karena ketersinggungan (manufactureofoffense). Seseorang dipidana karena pernyataan atau perbuatannya yang menimbulkan ketersinggungan, yang biasanya diekspresikan dalam penyerangan, kerusuhan atau mobilisasi massa. Kelompok "mayoritas" sebagai kelompok yang secara numerik belum tentu besar, namun mendominasi wacana, mampu melakukan mobilisasi, serta mengklaim-diri sebagai perwakilan dari masyarakat. Inilah yang sering tampak dalam kasus-kasus penyimpangan atau penodaan agama. Ketidakseimbangan relasi kuasa itu tentu saja juga dipengaruhi oleh kekuatan negara- ketika negara lemah dalam hal penegakan hukum, kelompok-kelompok tertentu dalam masyarakat, atas nama penjagaan tatanan sosial dalam persepsi mereka, dapat memaksakan kehendaknya (hal 28).

Dengan demikian, apa yang terjadi dalam konsep pembatasan di Indonesia, khususnya terkait dengan 
pembatasan untuk melindungi ketertiban masyarakat, memiliki dua karakter utama yaitu, (1) karakternya yang seringkali bersifat diskriminatif karena digunakan terutama untuk kepentingan yang mengatasnamakan "mayoritas", sebagaimana dibahas di atas, dan (2) justifikasinya oleh negara yang bersandar lebih pada UU yang berlaku, dengan pendekatan hukum tata-negara, bukan pada norma-norma HAM.

Dalam praktiknya di Indonesia, argumen ketertiban umum seringkali digunakan untuk membatasi hak untuk kebebasan beragama atau berkeyakinan dan hak untuk kebebasan menyampaikan pendapat. Ini dapat dibandingkan dengan kasus-kasus di luar negeri, di mana ketertiban masyarakat lebih kerap digunakan dalam konteks kebebasan berekspresi dan kebebasan berkumpul, bukan KBB (hal 29).

Di Indonesia, jenis kasus paling menonjol terkait ini adalah implementasi UU No.1/PNPS/1965 tentang pencegahan penyalahgunaan atau penodaan agama dan Pasal 156 A KUHP yang terkait. Dalam 15 tahun terakhir, penggunaan pasal ini mengalami peningkatan. Semua kasuskasus pengadilan dengan pasal ini dipicu oleh protes masyarakat, yang kemudian ditanggapi pihak kepolisian dengan penggunaan pasal ini. Dalam hampir semua kasus, "ketertiban masyarakat" dianggap terganggu, tidak sebagai akibat langsung dari ujaran atau tindakan pihak yang kemudian menjadi tersangka, tapi dari protes atas tindakan tersebut yang melibatkan mobilisasi massa dan dengan demikian menjadi bukti adanya gangguan atas ketertiban masyarakat (hal 30).

Terkait hal tersebut, buku ini merekomendasikan, pertama, perlunya melakukan penjernihan konseptual atas ide mengenai pembatasan. Istilah ketertiban umum/masyarakat, yang digunakan dalam penerjemahan resmi ICCPR ke bahasa Indonesia, dapat dipertahankan, namun konsepnya perlu dijernihkan dan ditunjukkan perbedaan maupun kaitannya dengan "ketertiban umum" dalam KUHP. Kedua, perlu diharmoniskan dengan pemahaman "ketertiban masyarakat" sebagaimana yang ada dalam norma HAM. Pertimbangan pembatasan perlu memperhatikan bukan hanya UU yang ada, tapi juga dengan norma HAM (hal 31).

\section{Keselamatan Masyarakat}

Buku ini menjelaskan, prinsip Sirakusa menerjemahkan keselamatan publik sebagai perlindungan terhadap bahaya untuk keselamatan orang, untuk hidup mereka, atau integritas fisik, atau kerusakan parah terhadap benda milik mereka. Prinsip Sirakusa selanjutnya mengatakan keperluan untuk melindungi keselamatan publik dapat menjustifikasi pembatasan yang dilakukan melalui hokum (hal 33).

Sementara itu, dokumen HAM mengartikan keamanan nasional sebagai ancaman terhadap suatu bangsa, wilayah, dan kemerdekaan politik melawan suatu kekuatan atau ancaman kekuatan bersenjata. Sedangkan keselamatan tidak terkait dengan kekuatan bersenjata. Konsep yang dalam pengertian umum dapat dianggap dekat dengan keamanan nasional adalah darurat umum (public emergency). Darurat umum adalah suatu keadaan yang mengancam kehidupan bangsa dan keberadaannya. Darurat umum terkait dengan apakah suatu hak dapat dikurangi pelaksanaannya (derogable). Derogable jelas berbeda dengan pembatasan (limitation). Pasal 18 Kovenan Hak Sipil Politik merupakan nonderogable rights tetapi memperoleh subyek dari pembatasan-dengan kata lain, dapat dibatasi (hal 36).

Prinsip Sirakusa mengartikan keselamatan umum sebagai perlindungan 
dari bahaya terhadap keselamatan orang, hidup dan integritas/keutuhan fisik atau kerusakan serius dari barang-barang milik mereka (hal 39).

Selanjutnya buku ini menuliskan, praktik pembatasan kebebasan beragama atau berkeyakinan di Indonesia menunjukkan pelaksanaan hak di masyarakat tidak menjadi acuan bagi penegak hukum. Faktafakta menunjukkan pembatasan yang tidak sah dengan alasan mengganggu ketertiban karena adanya massa yang menyerang, justru membuat masyarakat belajar bahwa menyerang orang lain dapat menjadikan alasan yang sah yang digunakan pemerintah. Akibatnya penyerangan-penyerangan justru marak terjadi di mana-mana dan terjadilah gangguan ketertiban yang lebih serius (hal 43).

Terkait hal tersebut, buku ini menuliskan tiga rekomendasi yang dapat diturunkan dari pembahasan di atas. Pertama, kata "keamanan" dalam penerjemahan Pasal 18 (3) ICCPR harus diganti menjadi "keselamatan". Kedua, harmonisasi seluruh peraturan perundang-undangan terkait pembatasan kebebasan beragama atau berkeyakinan amat mendesak dilakukan, agar tidak membatasi di luar yang ditentukan Pasal 18 (3) ICCPR. Ketiga, praktik pembatasan kebebasan beragama atau berkeyakinan di Indonesia perlu diubah dari pendekatan keamanan dan ketertiban menjadi pendekatan pemenuhan hak bagi korban.

\section{Kesehatan Masyarakat}

Buku ini menjelaskan, bahwa pembahasan tentang kesehatan publik atau kesehatan masyarakat tidak dapat dipisahkan dari hak atas kesehatan yang sudah diakui dalam Deklarasi Universal Hak Asasi Manusia dan Kovenan Internasional Hak Ekonomi, Sosial, dan Budaya. Hak atas kesehatan bukan hanya terkait layanan kesehatan tapi juga semua faktor yang menentukan kesehatan seperti akses pada air bersih, adanya persediaan makanan, nutrisi, dan perumahan yang aman, kondisi lingkungan yang mendukung, akses informasi terkait kesehatan, dan yang terpenting adalah partisipasi populasi yang paling terkena dampak dalam pengambilan kebijakan terkait kesehatan baik di tingkat komunitas, nasional, maupun internasional.

Dalam konteks kesehatan, definisi publik atau masyarakat dapat dikontraskan dengan individu. Publik di sini adalah orang banyak, dan biasanya satu komunitas dapat berbasis area geografis maupun kelompok orang dengan identitas tertentu. Kesehatan masyarakat atau kesehatan publik jelasjelas menyasar pada kesehatan seluruh orang yang ada di sebuah wilayah atau komunitas tertentu. Jadi, kesehatan masyarakat bukan hanya tentang penyakitnya tapi perilaku individu atau masyarakat yang berbahaya bagi kesehatan, baik individu maupun masyarakat, apalagi ketika itu kemudian bisa endemik atau menular dan meluas (hal 49).

Selanjutnya buku ini merumuskan, kesehatan masyarakat adalah segala upaya yang dilakukan untuk mencegah terjangkit penyakit, mempromosikan kesehatan dan mendorong harapan hidup yang lebih baik bagi masyarakat. Adapun cakupan kesehatan masyarakat meliputi: Epidemiologi dan biostatiska; kesehatan lingkungan; pendidikan kesehatan dan perilaku; administrasi kesehatan masyarakat; gizi kesehatan masyarakat; kesehatan dan keselamatan kerja; kesehatan reproduksi; sistim informasi kesehatan; dan, terakhir, surveilens penyakit menular dan tidak menular.

Menurut buku ini, ketegangan antara KBB dan hak atas kesehatan muncul dari konsep kesehatan masyarakat di 
atas. Negara memiliki kepentingan generasi mendatang yang sehat, dan ada hak individu yang ingin sehat, namun ada hak individu lain untuk menolak tindakan pertolongan berdasarkan agama. Tiga kepentingan ini harus dinegosiasikan. Beberapa kasus perilaku yang mengancam kesehatan masyarakat di Indonesia sangat dekat dengan masalah ajaran agama dan konstruksi gender yang membuat relasi kuasa yang timpang, tapi sayangnya kasus ini masih luput dari pengaturan norma. Di antara contohnya adalah kasus penolakan imunisasi karena dianggap haram atas alasan penggunaan bahan dari babi yang dianggap haram oleh ajaran Islam. Padahal imunisasi itu penting untuk mencegah meluasnya penyakit-penyakit tertentu (hal 52). Contoh lainnya adalah kewajiban vaksin untuk menjalankan ibadah haji yang ditolak oleh beberapa peserta ibadah haji karena dianggap tidak halal.

Konflik antara KBB dan hak atas kesehatan adalah konflik tiga kepentingan: antara hak individu sebagai warga negara yang mungkin memiliki keberatan atas dasar agama, hak individu lain yang ingin sehat, dan kepentingan negara untuk memastikan generasi akan datang yang sehat. Mencermati adanya berbagai persoalan tersebut, buku ini merekomendasikan pengaturan norma standar yang dapat memberikan parameter yang jelas bagi pembatasan untuk perlindungan kesehatan masyarakat.

\section{Moral Masyarakat dan Nilai-Nilai Agama}

Konsep pembatasan HAM berdasarkan "moral masyarakat" belum muncul dalam Deklarasi Universal Hakhak Asasi Manusia (Duham) 1948, tetapi mulai muncul dalam instrumen HAM setelahnya, yaitu Kovenan Internasional Hak-hak Sipil dan Politik (ICCPR) 1966.
Prinsip Sirakusa dengan jeli mencermati ICCPR yang menggunakan kata jamak untuk morals. Dengan menyebut "public morality varies over time and from one culture to another". Prinsip Sirakusa mengakui eksistensi ragam moralitas yang tidak sui generis, tapi moralitas merupakan konstruksi yang dapat berubah dari waktu ke waktu dan dapat berbeda dari satu budaya dengan budaya lain.

Oleh sebab itu, konsep moral masyarakat adalah turunan dari beragam tradisi agama, filsafat dan sosial. Dengan demikian, ia bersifat melampaui satu tradisi agama atau budaya tertentu. Kasus yang sering dijadikan contoh adalah diskresi negara yang dibenarkan untuk melarang praktik ritual seks bersamasama di muka umum untuk melindungi norma agama-agama (yang jamak) dan adat yang hidup di masyarakat. Pembatasan tersebut dilakukan negara untuk melindungai ragam moralitas (hal 64).

Negara memberikan diskresinya dalam membatasi kebebasan untuk melindungi moralitas masyarakat harus tetap mempertimbangkan rasa keadilan. Hal ini mengantarkan pentingnya berbicara mengenai institusi moralitas dan relasi kuasa yang dinamis di sebuah negara atau masyarakat.

Setiap individu sebenarnya memasang standar moral untuk dirinya, yaitu standar yang menentukan kebolehan, ketidakmungkinan, dan tindakan yang dianggap salah (blameworthiness). Oleh karena bersifat individual, ceruk perbedaan moral antara satu individu dengan individu yang lain sangat luas, meskipun tetap ada persamaan tertentu.

Di Indonesia, kelompok pejuang HAM mengaitkan imoralitas dengan dehumanisasi. Sementara itu, kelompok lain (pada umumnya religius) banyak menghubungkan moralitas dengan 
nilai-nilai agama, etiket, dan kesusilaan. (hal 68). Institusi moral mengemuka karena keberadaan ragam individu yang mengikatkan diri secara sukarela secara bersama-sama dalam lembaga sosial. Di sini institusi moral berfungsi sebagai tali pengikat yang menjadikan individu lebih konsisten terhadap moralitas dan nilai yang diyakini.

Pembatasan kebebasan untuk melindungi moral masyarakat di Indonesia banyak memunculkan perdebatan. Misalnya, penggerebekan terhadap laki-laki dan perempuan bukan suami-isteri yang berhubungan intim di ruang tertutup. Lalu, seruan kepada perempuan bukan Muslim untuk memakai jilbab di sekolah negeri untuk menyesuaikan moralitas umum yang bersumber dari ajaran agama di sekolah. Contoh lain adalah kriminalisasi kegiatan LGBT dan hubungan sejenis di ruang privat dan pandangan yang menyebutkan perempuan yang memakai pakaian minim wajar jika diperkosa.

Selain moral masyarakat, dalam buku ini juga dijelaskan terkait nili-nilai agama sebagai pembatasan KBB. Terkait nilai-nilai agama dalam masyarakat Indonesia, hal itu bisa dipandang sebagai sebuah shared values dari agama (atau agama-agama) yang hidup di masyarakat. Kata agama di sini tidak mengacu pada agama tertentu.

Sebagaimana telah disebutkan, kebebasan beragama dicantumkan dalam Pasal 29 UUD 1945. Setelah amandemen konstitusi, selain dalam Pasal 29, kebebasan beragama mendapat penekanan kembali di Pasal 28 E (1) "Setiap orang bebas memeluk agama dan beribadat menurut agamanya..."; (2) "...kebebasan meyakini kepercayaan, menyatakan pikiran dan sikap, sesuai dengan hati nuraninya".

Setidaknya ada dua perbedaan pandangan atau paradigma dalam melihat pembatasan kebebasan atas dasar nilai-nilai agama. Pertama, pandangan yang menyebutkan bahwa "salah satu pembatasan atas hak asasi manusia adalah nilai-nilai agama... berati nilainilai agama berada di atas HAM". Dalam praktik hukumnya yang terjadi di Indonesia, misalnya Keputusan MK No.140/PUU-VII/2009, menyebutkan bahwa pembatasan berdasarkan nilai-nilai agama tampaknya menjadi pertimbangan hakim untuk tidak mengabulkan JR UU PNPS No. 1 Tahun 1965. Nilai-nilai agama di situ ditafsirkan sebagai teologi yang benar menurut mayoritas ortodoksi agama (Keputusan MK No.140/PUUVII/2009, 274-275; Bagir 2015: 147).

Kedua, pandangan sebaliknya, dimana nilai-nilai agama (dan pembatasan lain dalam Pasal $28 \mathrm{~J}$ ) dipahami bersifat umum, karena itu tidak dapat membatasi tujuh hak khusus yang disebut dalam Pasal 28 I yang salah satunya kebebasan baragama; kebebasan beragama tidak bisa dibatasi dengan nilai-nilai yang bersifat umum. Polemik dan konstestasi tafsir mengenai pembatasan kebebasan berdasarkan nilai-nilai agama bergerak dalam dua kutub tersebut (hal 72).

Dalam buku ini juga disebutkan, bahwa konsep limitasi hak atas dasar nilai-nilai agama dipakai secara ekstensif dalam proses persidangan dan putusan Uji Materi UU No. 1/PNPS/Tahun 1965 tentang Pencegahan Penyalahgunaan dan/atau Penodaan Agama pada tahun 2009, terutama oleh pemerintah dan sebagian Pihak Terkait yang dihadirkan oleh pemerintah yang kemudian banyak diamini oleh hakim MK, dan keputusan MK adalah menolak permohonan dalam uji materi UU tersebut. Pembatasan berdasar nilai-nilai agama tersebut dipahami sebagai penyeimbang dari HAM yang dianggap absolut. Artinya, klausul-klausul pembatasan, tidak terkecuali pembatasan berdasar nilainilai agama, berfungsi untuk melucuti sifat dasar HAM yang absolut. Sehingga 
di Indonesia tidak ada HAM yang bersifat mutlak. Pembatasan mengenai nilainilai agama sebagai nilai-nilai komunal (communal values) masyarakat adalah pembatasan yang sah menurut konstitusi (hal 76).

Selanjutnya, menanggapi pembatasan melalui moral masyarakat dan nilai-nilai agama tersebut, buku ini merekomendasikan tiga hal. Pertama, penting menekankan bentuk kata jamak "morals" dalam Pasal 18 (3) ICCPR . Kedua, mengembalikan polemik moralitas pada ranah masyarakat sipil dan jika negara "terpaksa" mengambil diskresi dalam masalah ini negara harus benarbenar mempertimbangkan keadilan sosial. Ketiga, baik negara maupun masyarakat sipil harus menghormati ruang privat individu dalam masalah moralitas, kecuali dalam kasus-kasus spesifik seperti pencegahan terhadap upaya pembunuhan dan pemerkosaan.

\section{Kritik atas Prinsip Sirakusa}

Pembatasan atas hak KBB tercantum eksplisit dalam kovenan ICCPR, konstitusi UUD 1945, maupun peraturan perundang-undangan yang ada. Meski terdapat redaksi yang tidak konsisten, namun secara umum pembatasan itu dibagi dalam lima hal yaitu: (1) ketertiban masyarakat, (2) keselamatan masyarakat, (3) kesehatan masyarakat, (4) moral masyarakat dan nilai-nilai agama. Buku ini secara cermat mengkritisi adanya cara pandang yang berbeda dalam memahami batasan dalam memaknai empat norma tersebut, baik antara kelompok masyarakat tertentu dengan pemerintah, maupun intrakelompok dalam masyarakat, termasuk keputusan pengadilan atas kasus-kasus tersebut. Dalam pembahasan buku ini, ditawarkan prinsip-prinsip Sirakusa; sebuah panduan bagi pemerintah dalam menterjemahkan pembatasan yang disepakti pada tahun 1984 di Sirakusa, Italia.
Secara umum, pandangan tersebut bisa diterima. Pengenalan prinsip Sirakusa dalam buku ini penting dikaji secara lebih serius oleh para pihak yang terlibat dalam mengawal KBB di tanah air. Namun demikian, tidak berarti tanpa pemikiran kritis. Kritik atas buku ini, justru terletak pada perspektif yang dipakai buku ini yang melandasi norma pembatasan tersebut dengan menggunakan prinsip-prinsip Sirakusa, sebagai satu-satunya prinsip. Melalui cara pandang demikian, sebagaimana telah diuraikan di atas, sejumlah peraturan perundangan-undangan dan jurisprudensi yang ada, dipersoalkan. Ini bisa dilihat, misalnya penolakan buku ini atas norma dalam UU PnPs 1965, maupun atas keputusan-keputusan pengadilan dalam penyelesaian sejumlah kasus keagamaan di tanah air.

Penulis menilai, Pancasila sebagai sumber hukum, perlu menjadi prinsip utama dalam memberikan tafsiratassegala norma dalam peraturan perundangan yang ada. Sehingga, perspektif yang ada dalam prinsip Sirakusa, bukan satu-satunya, tapi perlu disandingkan bersama nilai-nilai yang ada Pancasila. Ini tidak berarti mempertentangkan Pancasila dengan Sirakusa, sebab dalam Pancasila juga terdapat sila Kemanusiaan, yang itu berarti menghormati prinsip kemanusiaan sebagaimana yang ada dalam prinsip HAM.

Selain sila Kemanusiaan, dalam pancasila terdapat sila Ketuhanan, artinya nilai-nilai agama merupakan landasan "pembentukan undangundang", jadi tidak hanya dipahami dalam konteks sebagai pembatasan hak. Dengan kata lain, logikanya nilai-nilai agama harus menjadi nilai yang integral dalam pembentukan suatu UU. Sehingga produk hukum yang tidak sesuai dengan nilai-nilai agama bisa dianulir. Dalam hal bagaimana jika pembatasan itu atas norma moral atau nilai-nilai agama yang 
diyakini oleh individu-individu? Penulis berpendapat bahwa nilai-nilai agama di situ, perlu ditafsirkan sebagai teologi yang benar menurut mayoritas ortodoksi agama, dan bukan individual, bukan individual.

Namun demikian, harus diakui, ada hal krusial dalam mengusung nilainilai agama sebagai pembatasan KBB. Pertama, apakah agama itu dan siapakan saja kelompok agama itu? pendefinisian agama di Indonesia sebenarnya belum pernah ditetapkan secara eksplisit. Padahal pendefinisian itu sangat penting. Selama ini karena pendefinisian yang tidak tuntas, beberapa kelompok yang merasa dirinya agama, tapi kemudian teranulir. Satu-satunya konsideran terkait agama terdapat dalam penjelasan Pasal 1 dari UU No. 1/PnPs/1965 yang menyebutkan: "Agama-agama yang dipeluk oleh penduduk di Indonesia ialah Islam, Kristen, Katolik, Hindu, Budha dan khong $\mathrm{Cu}$ (Confusius). Hal ini dapat dibuktikan dalam sejarah perkembangan agama-agama di Indonesia. Karena 6 macam Agama ini adalah agama-gama yang dipeluk hampir seluruh penduduk Indonesia, maka kecuali mereka mendapat jaminan seperti yang diberikan oleh pasal 29 ayat 2 Undang-undang Dasar, juga mereka mendapat bantuan-bantuan dan perlindungan seperti yang diberikan oleh pasal ini. Ini tidak berarti bahwa agamaagama lain, misalnya: Yahudi, Zarasustrian, Shinto, Taoism dilarang di Indonesia. Mereka mendapat jaminan penuh seperti yang diberikan oleh pasal 29 ayat 2 dan mereka dibiarkan adanya, asal tidak melanggar ketentuan-ketentuan yang terdapat dalam peraturan ini atau peraturan perundangan lain." Penjelasan tersebut, memang tidak hanya mengakui 6 agama, tapi juga agama-agama lain, namun tetap saja belum memberikan pengertian yang definitif.

Kedua, selain memiliki banyak jenis agama, dalam satu agama juga ada banyak tafsir keagamaan, dalam sebuah masyarakat yang berkontestasi, bagaimana apabila terdapat benturan antarnorma moral di dalam masyarakat? Yang mana yang penting dikedepankan? Fenomena ini tidak mudah diselesaikan. Dalam banyak peristiwa di tanah air, pihak yang dimenangkan adalah tafsir kelompok memiliki banyak massa. Kasus semacam ini banyak terjadi, misalnya dalam kasus adanya suatu aliran sesat, fenomena tersebut, biasanya diikuti dengan upaya sekelompok orang untuk mempengaruhi publik bahwa kelompok tersebut memang sesat, yang biasanya diiringi dengan fatwa ormas tertentu (MUI). Pada akhirnya, pemerintah atau pengadilan melarang "aliran sesat" tersebut. Selanjutnya, kelompok yang dianggap sesat tersebut akan dibatasi.

Mencermati, problem-problem tersebut, ada dua rekomendasi yang ditawarkan, dengan basis nilai-nilai Pancasila. Pertama, perlu rumusan definisi terkait apakah agama itu. Definisi agama tersebut diperlukan, untuk adanya kesepahaman bersama tentang agama, jangan sampai ada kelompokkelompok keagamaan tertentu yang tidak memperoleh haknya karena pendefinisian itu. Definisi agama harus mengakomodir segenap agama dan keyakinan masyarakat yang ada di Indonesia, baik yang berasal dari luar mapun dari leluhur/lokal/nusantara. Penghormatan atas agama-agama tersebut harus setara dan tidak boleh ada diskriminasi, meski dengan keterbatasan yang dimiliki pemerintah, ada keterbatasan dalam hal bentuk pelayanan yang diberikan.

Kedua, dalam beberapa kasus pembatasan KBB di tanah air, ternyata melahirkan serangkaian konflik. Hal ini tidak lepas dari adanya batasan yang masih multi tafsir. Persoalan pembatasan $\mathrm{KBB}$, tidak bisa diselesaikan melalui jalur peradilan pidana. Persoalan keagamaan memiliki nilai subjektivitas yang tinggi, sehingga mustahil bisa ditampung 
seluruhnya dalam KUHP. Dalam penyelesaian kasus hukum dikenal istilah "yuridis" dan "non yuridis". Penyelesaian kasus-kasus keagamaan, perlu dirumuskan dalam hukum acara di KUAHP, yang mengakomodir penyelesaian melalui "non yuridis", misalnya dengan proses dialog atau mediasi. Selama ini, kasus-kasus konflik terkait KBB, lebih banyak terjadi karena salah paham, prejudaice, ketersinggungan, atau perbedaan penafsiran, sehingga proses "non yuridis" sangat tepat. Ini tidak berarti menegasikan proses "yuridis", misalnya dengan menggunakan azas ultimum remedium, yaitu azas dalam hukum pidana, dimana sanksi pidana adalah upaya terakhir dalam penegakan hukum. Contoh semacam ini sudah banyak terjadi, misalnya dalam kasus tuduhan sesat terhadap LDII dan Jam'iyyatul Islamiyah. Melalui proses dialog yang dilakukan oleh MUI dan kedua ormas tersebut, kedua organisasi tersebut dapat mengklarifikasi tuduhantuduhan "sesat" yang dialamatkan pada mereka, hingga kemudian tetap dapat diakui sebagai bagian umat Islam. 